DOI: https://doi.org/10.47405/aswj.v5i2.137

\begin{tabular}{|c|}
\hline $\begin{array}{c}\text { Asian SOCIAL WORK } \\
\text { JURRAL } \\
\text { (ASW) }\end{array}$ \\
Volume 5, Issue 2, July 2020 \\
\hline \\
\hline
\end{tabular}

\title{
Factors Which Contribute to Students' Persistence: A Study on "Sahabat Anak" Non-Formal School for Marginal Children
}

\author{
Natalia Ajiningtyasasih ${ }^{1}$, Fentiny Nugroho ${ }^{1}$ \\ 1Department of Social Welfare, Faculty of Social and Political Sciences, Universitas Indonesia \\ Correspondence: Fentiny Nugroho (fentiny2015@gmail.com)
}

\begin{abstract}
Generally, the school drop-out rate of marginal children is high. However, some of them have high persistence and can complete their education. This research aims to describe the factors that play a crucial role in forming student persistence and analyze efforts and challenges encountered by Pusat Kegiatan Anak (PKA/Children's Activity Center) "Sahabat Anak" in maintaining and increasing their students' persistence. This study used a qualitative approach with descriptive research. Data collection techniques employed are in-depth interviews and documentary studies involving four school alumni who have continued their education to formal schools, two teachers, and two education staff of PKA "Sahabat Anak" Non-formal School. This study finds that social support from parents and closest people is a very significant factor in building the persistence of students of PKA "Sahabat Anak" Nonformal School. The School makes efforts to build children's persistence by conducting quarterly evaluations, parental training, and a home visit. However, influences from the social environment become a big challenge for these efforts. Social workers shall play a key role in addressing these issues.
\end{abstract}

Keywords: student persistence, non-formal school, school drop out, marginal children

\section{Introduction}

Education and school life are part of child welfare (Ben-Arieh \& Frones, 2011). According to BenArieh and Frones, Child welfare includes the concept of being (object or state), the life experienced at present, and the concept of becoming which covers the change and development of life in the future as an adult. Thus, education is one of the efforts to help develop each child's personality and ability to improve the quality of his welfare in the future. Nevertheless, in reality, a decent school cannot always be obtained by every Indonesian child. There are still many children who do not have the opportunity to attend a school or unable to finish school/drop out for various reasons. The Center for Data and Statistics of Ministry of Education and Culture, Republic of Indonesia mentioned that during 2018/2019, in DKI Jakarta, there are 7,672 students at the Elementary School through High School and Vocational School are drop-out. Muller in Suyanto (2019: 137) states that the primary variable causing children's opportunities to obtain an education is hampered due to poverty and institutional structural inequality. As a result of poverty and lack of parents' interest in the importance of education, children are voluntary or forced to become an essential source of family income (Suyanto, 2010). Consequently, children must leave school and work to support the family economy.

The children, who drop out of school, would be left behind in various academic knowledge and skills. To catch up and keep growing, they need specialized education pathways that fit their needs that 
DOI: https://doi.org/10.47405/aswj.v5i2.137

cannot be found in formal schools. Thus, one of the protective actions and support provided for them is non-formal education programs. Law (UU) No.20 of 2003 about National Education System Article 26 (1) states that non-formal education is held for citizens who need educational services that function as substitutes, additions, or complementary formal education to support lifelong education. Through non-formal education, life skills in the form of specific skills or expertise can be obtained through various training activities that enable students to adapt to the workforce world or entrepreneurship so that their welfare is assured (Alifuddin, 2011: 93-94).

One non-governmental organization that provides non-formal education, especially for marginalized children (including street children) dropping out of School in Jakarta, is "Sahabat Anak" Jakarta Community Foundation. "Sahabat Anak" is an institution driven by volunteers fighting for the protection and fulfillment of children's rights, especially street children (on the street, of the street, vulnerable to be on the street). It provides free tutoring education, scholarships, kindergarten/early education, non-formal schools, libraries, healthy food, counseling, health checks, and advocacy. As a place for coaching and learning that is more intensive and holistic, especially to street children who have dropped out of School, "Sahabat Anak" established a Non-Formal School named Children's Activity Centers (PKA) in 2006. Over 13 years of existence, PKA "Sahabat Anak" has sent some street children that drop-out of School in the Jakarta area to return to School and various formal education/training institutions even to universities. During the implementation of its programs, challenges faced by PKA "Sahabat Anak" in educating their students. One of the challenges that PKA "Sahabat Anak" always encounters from year to year is the high rate of student turnover and the low rate of student attendance in learning activities. For the last six years (2014 - 2019), 134 students joined the program, and 127 students did not continue their learning activities to completion. Only 16 children completed their learning process and continued to the next stage, either formal schools or other educational institutions. The students who do not continue the learning process mostly come from broken families, poor and parents' lack of awareness of the importance of education for their children.

In Ajisuksmo's research (2012), based on his discussions with the NGO tutors dealing with street children's in Bandung, it was revealed that the most challenging part in educating street children and child labor, was motivating them to learn because they had dropped out of School and spent most of the time on streets or workplaces. Meanwhile, students need to be persistent in order to succeed. Seligman \& Peterson (2004: 229) defines persistence as "voluntary continuation of goal-directed action despite obstacles, difficulties, or discouragement." The persistent students will still struggle to participate in learning activities despite challenges in the process. Persistence is crucial for students; it is one of the strong characters possessed by individuals and is needed for the completion of every assignment. The students who have high persistence are successful in completing any task being carried out.

Astri (2014) states that the absence from the classroom for teaching and learning is still one of the problems in handling street children. Their absence in classroom learning activities is more due to their lack of interest in studying at School. It is related to the orientation of getting money on the street rather than going to School. A very diverse range of triggers allows street children to undo their intentions and become uninterested in being in a classroom full of rules. Moreover, according to some research results, child laborers and street children are not interested in continuing school because, to them, School is regarded as a burden and does not have a significant impact on the additional wages they can earn. Schools are also "luxuries" that they cannot reach, even if they are free (Thamrin, 1996).

Among PKA "Sahabat Anak" students who do not continue their education until completion, there are students who are persistent in the program until completion and continue to formal School or other educational institutions/courses. The students remain persistent in terms of some aspects: the attendance to participate in learning activities in PKA "Sahabat Anak" routinely and completion of the learning process until continuing to a higher level of education, both in formal schools or other educational institutions. Meanwhile, previous studies related to student's persistence still focused more on formal school students, for example, those conducted by Lori A. Kuhns (2014), Sarita Y. 
DOI: https://doi.org/10.47405/aswj.v5i2.137

Shukla et al. (2015) and George D. Kuh (2007), the persistence of drop-out children in non-formal schools has not yet become a research focus. Based on the research gap, this research is the factors contributing to the persistence of school drop-outs' student who continues their education at a nonformal school. It is not easy for children who drop out of school and live in poverty to maintain a high level of persistence and motivation amid in the limitations and obstacles they face, so this motivates the researchers to conduct research on the persistence with following research questions:

i. What are the factors that play a role in the persistence of students of PKA "Sahabat Anak" non-formal school?

ii. What are the efforts and challenges encountered by PKA "Sahabat Anak" to maintain and increase the persistence of PKA "Sahabat Anak" non-formal school students?

\section{Research Methodology}

This study used a qualitative approach. Creswell states that qualitative research is a means for exploring and understanding individuals or groups ascribe to a social or human problem (Creswell, 2009: 4). The type of this research is descriptive research that aims to provide a specific description of the factors that influence the persistence of non-formal PKA "Sahabat Anak" school students. Data collection includes primary and secondary data carried out with literature studies, documentation, and in-depth interviews. In-depth interviews involved four alumni students, two teachers, and two education staff.

\section{Results and Discussion}

Participants from alumni group participants have dropped out of formal School due to the economy and family problems, including nomadic residences (migrating from their hometown to capital city Jakarta). During the school drop-out, the students' activities were only playing with friends, and some were busking to fulfill their daily life. After completing their education in PKA "Sahabat Anak" nonformal schools they continue their education to formal schools.

Table 1: Participants - Alumni Students

\begin{tabular}{|c|c|c|c|c|c|c|}
\hline Participant & Gender & $\begin{array}{c}\text { Age } \\
\text { (year) }\end{array}$ & $\begin{array}{l}\text { Drop out } \\
\text { (grade) }\end{array}$ & $\begin{array}{l}\text { Present } \\
\text { (grade) }\end{array}$ & $\begin{array}{c}\text { Length } \\
\text { of study } \\
\text { in PKA } \\
\text { SA }\end{array}$ & $\begin{array}{l}\text { The closest } \\
\text { person who } \\
\text { gives social } \\
\text { support }\end{array}$ \\
\hline YS & Male & 19 & 2 & 11 & 3 year & Ms. A (teacher) \\
\hline NS & Male & 18 & 5 & 11 & 2 year & Ms. T (neighbor) \\
\hline JA & Female & 19 & 3 & $\begin{array}{l}12 \\
\text { (graduated) }\end{array}$ & 9 month & Parent (mother) \\
\hline $\mathrm{RP}$ & Male & 19 & 6 & $\begin{array}{l}12 \\
\text { (graduated) }\end{array}$ & 2 year & Parent (mother) \\
\hline
\end{tabular}

Table 2: Participants - Teacher \& Education Staff

\begin{tabular}{lllc}
\hline Participants & Gender & \multicolumn{1}{c}{ Position } & $\begin{array}{c}\text { Length of work } \\
\text { (year) }\end{array}$ \\
\hline LM & Female & Guru Bahasa Indonesia \& Life skill Teacher & 14 \\
LS & Female & Character Building Teacher & 14 \\
KA & Female & Education staff & 7 \\
CR & Male & Education staff & 8 \\
\hline
\end{tabular}




\title{
Factors that play a role in shaping the persistence of PKA "Sahabat Anak" non- formal school students
}

It is not easy for students to begin to study and take lessons in PKA "Sahabat Anak" because they have dropped out of School; therefore, they are left behind in many lessons. Further, learning is far from where they live, laziness to go to School, feeling insecure or unconfident, challenging to adapt in a friendly environment, and temptation from the environment that persuade them to give up School are also obstacles encountered by students.
"Yeah, I often persuaded to play the game.. 'what are you doing in school, why are you going to PKA.. all the way better playing here... just playing Play Station. That is the challenge from the outside. We know how the environment is a slump environment where the house is in the front and back of the other house. Here is also so many of friends who do not go to School. So sometimes many of them join their drop out friends and not going to School. " (NS, alumni student)

In passing each of these obstacles, the parent's social support was the most critical factor in supporting them to remain persistent in completing their education at PKA "Sahabat Anak."
"Mom, the factor for me to continue, to fight. That must be the most important. The thing is, I am close to mom, so every time I have any problems, I will talk to mom. " (JA, alumni student)

For two students (YS and NS) who do not live with parents, support for staying in School is obtained from the closest people such as neighbors, mentors, or teachers who care deeply about their education. Their support is in the form of freedom of time to go to school, advice, advice, and motivation that can make them able to return to school enthusiasm and provide assistance in school homework.

\begin{abstract}
"My neighbor. Until now, she always supports me for School; her name is Mbak TN. She supports me the most, even rebukes me; she was just like my second parent. Supporting me to School like that, so it is not like the other kids here. " (NS, alumni student)

"For example, when I want to go to School, everything is supported by my mom 'as long as you want to go anywhere you want to do, remember to back home, consider the time, so I am not too depressed, I mean I am not so restrained. " (RP, alumni students)
\end{abstract}

This relationship has helped students to overcome their challenges. The findings above are in line with Zaleski's research in Seligman \& Peterson (2004: 241), finding that people who have close and supportive relationships are more able to survive and exert effort than those who do not have that relationship. Furthermore, in his research Lawton-Sticklor (2018) shows that the cultural wealth that students receive from interactions with families is an integral part in motivating them to survive through obstacles in School.

\section{Social support helps students foster self-determination}

During the learning process at PKA "Sahabat Anak," invitations from the environment to stop. The advice and direction given by the student's closest people motivate and build confidence and play a role in reminding their initial motivation or goals in school.

\footnotetext{
"Yes, it is essential, in my opinion, because right, sometimes we forget our purpose for learning. Later it is desirable, so we remember again, oh yes, we aim to study it like this ... like this .... when we are reminded, we get excited again. "(YS, alumni student)
} 
DOI: https://doi.org/10.47405/aswj.v5i2.137

Besides, the support of the closest people has helped students think ahead and warn of the consequences of every decision. These make students rethink to decide to quit School again.

"Yes, actually the form of support just talks, but it makes me think like... 'You want to be like a busker again, meeting the pickpockets again, meeting gamblers again.' ... so you know. Finally, I decided to yeah.. who wants to be a pickpocket so.. her support made me think for the future. 'In the future, what do you want to be ... if you follow the other (drop out) kids like that' ... " (NS, alumni student)

The advice and motivation given by those closest persons have reminded their motivation or initial goal of learning. The consequences for each decision have enabled them to decide to remain in PKA "Sahabat Anak," in other words, building their self-determination. Deci \& Ryan (in Field, Hoffman \& Posch. 1997) defines self-determination from the perspective of psychology as "the capacity to choose and to have those choices be the determinants of one's actions, or it can also be said one's determination at a goal to be achieved. The research finding is in line with research conducted by Vallerand, Fortier, and Guay in Seligman \& Peterson (2004: 241), finding that self-determination mediated the link. Social support fostered a sense of self-determination, which predicted better academic persistence (measured by completing School instead of dropping out). Contrarily, a decrease of social support leads to the decrease of self-determination and the increase in the rate of school's drop-out.

\title{
Parental or closest person social support helps the teacher control the activities of students outside the School
}

One of the critical roles of social support from parents or the closest person is assistant to the teacher and education team in controlling and monitoring the students.

\begin{abstract}
"Because if there is no support from parents, it will be difficult for us to control. Because their children are from 9 am to $3 \mathrm{pm}$ (at School), the rest is with parents who control it if there is no support from their parents, it is will be difficult. " (CR, education staff)
\end{abstract}

"Someone is monitoring ... for example, they do not come (to School). We can check pe... it means there are in charge to check like that ..." (LM, teacher)

With the support of parents and those closest to the teachers and Education staff, they can work together in monitoring the developments or obstacles faced by students in participating in learning at School.

\section{Efforts and challenges in maintaining and enhancing the persistence of the target students}

Since it was established in 2006, PKA "Sahabat Anak" has carried out various programs to maintain and improve students' persistence. Through in-depth interviews conducted with two education staff and two teachers, efforts include:

\section{Quarterly evaluation and parental training}

In monitoring the student learning progress, PKA "Sahabat Anak" conducts a quarterly evaluation of learning outcomes by inviting parents to discuss student development with the teacher. Learning outcomes reports are used as feedback for students and parents to continue to be motivated to learn.

"The routine one is the quarterly evaluation once every three months by inviting the parents. So there will be cooperation between "Sahabat Anak" and parents as 
DOI: https://doi.org/10.47405/aswj.v5i2.137

supporters at home. We always understand that it is our goal to educate their children. " (CR, education staff)

"We, the teachers, are entirely supported by the parents gathering (at the quarterly evaluation), yes ... when the parents are invited, we are teachers, can discuss with the parents. Sometimes the reason why the student does not come in, the parents can explain. So that we finally found something about the case .. "(LM, teacher)

Besides providing the evaluation report of the development of student learning, the parent's meeting is held in parallel with the parenting seminar or workshop to increase the parents' knowledge in educating and assisting children in learning. These aspects are considered to be very important regarding the condition of most of the parents of the students are lack knowledge, low in the level of education even there are still many among those who are illiterate.

\section{Students' home visit}

The teacher and education staff visit the students' homes are conducted both regularly every three months and occasionally to the targeted students are who have not been attending the School for a week. In this visit, the Education Team tries to discover why students do not attend the School and motivate parents and the students to remain persistent in learning.

"First to his parents, we visited their home, just visited, even there was a point where we were too.. tired when we kept going. Nevertheless, there was a moment that because we kept coming, finally the student attends the School. " (KA, Education staff)

After students came back to study at PKA "Sahabat Anak," the teachers and staff reminded them again of the purpose and importance of their schooling. Through visits to students' homes, teachers and staff can also determine the conditions of the residence and environment of students to understand their social circumstances better.

\section{Challenges faced in implementing the program}

From the results of interviews with staff and teachers, the challenges in maintaining the students' persistence are often constrained by the decrease of learning motivation influenced by their environment that persuaded them to play or work and return to the street to make money rather than School.
"For example is SL now. He likes to parade ondel-ondel (large puppet figure from Betawi performed to make money) something like that ... even though almost every week we go to his house now, to discuss with his parents. " (CR, Education staff)
"In some cases, there were seen some students who did not come because they were already comfortable ... maybe they afford ten thousand in cash ... maybe they were just like pulling things out ... or washing motorcycles so they could get money" (KA, education staff)

Living in a densely populated environment where many children drop out of School, the influence of friends as a factor that makes students absent from School is very dominant. Besides, the ease of getting money from simple jobs is something more interesting for students compared to studying in School.

Further, this research shows that none of the social workers is hired at the studied institution. Therefore, this study strongly recommends that PKA"Sahabat Anak" should recruit the social worker. By applying knowledge, values, and skills, social workers can enhance the children's persistence and help decrease the rate of drop-out. Based on the research findings, the primary factor of students' 
persistence is social support from their parents and closest people. Social work is a profession that emphasizes "person in the environment." The profession helps disadvantaged people achieve their welfare, meaning the fulfillment of needs and opportunities to have education and decent work, so they are free of poverty, fear, anxieties and feel secure (Fahrudin, 2012). In this context, when the social worker works with the students, he/she can implement a micro-level intervention; the social worker empowers and motivates the child (as a person) and his parents, peer group, and closest people (as the environment).

There are some roles played by a social worker in carrying out duties (Zastrow, 1996), among others:

i. Enabler: to help the children express their feelings and needs, then together with them to determine a strategy to develop the personal capacity and deal with the problems effectively.

ii. Educator: Social workers must have good knowledge and understanding of the problem dealt with, and be able to communicate well. Training for parents, the social workers can give training on good parenting and support to children, so they are motivated to complete School.

iii. Broker: the social workers connect children and families with existing resources, government sources, and non-governmental (public) ones. For example, social workers can make connections with some Ministries to develop income-generating programs for the family.

iv. Facilitator: the social workers can lead to group activity, for example, group counseling. They can form groups of the children through play; the children will obtain psychosocial treatment. The social worker can also work with peer groups to support the children. The research results indicate that the children's environment (friends) is a challenge to their persistence in attending School and doing assignments. The social worker shall develop a fruitful collaboration between parents and the closest people of students and teachers in monitoring the students.

When working with marginal children, especially street children, social workers need to look at the world from the children's views and make attempts to understand their experiences, frustration, and hopes. As an empowering profession, everything done by a social worker must empower the children as clients, fulfill their rights, and help them pursuit a better future (Nugroho, 2012).

\section{Conclusion}

This study results indicate that the support of parents or the closest people of children is an essential factor influencing the persistence of PKA "Sahabat Anak" non-formal school students. Social support provided by parents and other closest people plays a crucial role in motivating, increasing selfdetermination, and assisting teachers in monitoring and controlling the students' activities while not in School. PKA "Sahabat Anak" efforts to invite parents to evaluate student learning outcomes every quarter, hold a parenting seminar or workshop and visit the homes of students who have attendance problems involving the role of parents or closest people of students in increasing student's persistence. In order to help students defend the influence of the environment to give up school, there needs to be a collaboration between parents and the closest people of students and teachers in monitoring students. The recruitment of social worker can help increase the students' persistence and therefore, can decrease the drop-out rate. Education is a bridge for the children to have a better future.

\section{References}

Alifuddin, M. (2011). Kebijakan Pendidikan Nonformal. Magna Script Publishing.

Ajisuksmo, Clara. (2012). Faktor-Faktor Penting Dalam Merancang Program Pendidikan Luar Sekolah Untuk Anak Jalanan Dan Pekerja Anak. Jurnal Makara, Sosial Humaniora, 16(1), 3648. 
DOI: https://doi.org/10.47405/aswj.v5i2.137

Astri, Herlina. (2014). Kehidupan Anak Jalanan di Indonesia: Faktor Penyebab, Tatanan Hidup Dan Kerentanan Berperilaku Menyimpang. Aspirasi: Jurnal Masalah-Masalah Sosial, 5(2). https://doi.org/10.22212/aspirasi.v5i2.454.

Ben-Arieh, A. \& Frones, I. (2011). Taxonomy for child well-being indicators: A framework for the analysis of the well-being of children. A Journal of Global Child Research, 18(4).

Creswell, John W. (2009). Research Design Qualitative, Quantitative, and Mixed Methods Approaches. (3rd ed.). SAGE Publications. Inc.

Dehumanisasi Anak Marjinal: Berbagai Pengalaman Pemberdayaan. Penyunting, Surya Mulandar; Pengantar, Juni Thamrin. Bandung: Yayasan Akatiga, 1996.

Draft Pendidikan Yayasan "Sahabat Anak". (2013). Divisi Pendidikan Yayasan Komunitas "Sahabat Anak" Jakarta.

Fahrudin, Adi. (2012). Pengantar Kesejahteraan Sosial. Bandung: Refika Aditama

Field, S., Hoffman, A., \& Posch, M. (1997). Self-Determination During Adolescence A Developmental Perspective. Journal of Remedial and Special Education, 18(5), 285-293

Kuh, George D., et al. (2007). Unmasking the Effects of Student Engagement on College Grades and Persistence. Centre for Postsecondary Research Indiana University Bloomington.

Kuhns, Lori A. (2014). Factors that Promote Persistence and Motivation Among Successful, High Poverty, Urban High School Students. Theses and Dissertations (All). 449. http://knowledge.library.iup.edu/etd/449.

Lawton-Sticklor, Nastasia. (2018). To Get Somewhere in Life: Family Support and Persistence in School, Clark University Critical Questions in Education 9:2 Summer 2018.

Nugroho, Fentiny. (2012). Social Services for Children of Mothers with HIV/AIDS, ASEAN Social Work Journal, February 2012

Peterson, C., Seligman, M. E. P. (2004). Character strengths and virtues: a handbook and classification. New York: Oxford University Press.

Shukla, Sarita Y., (2015). Parental Support for Learning and High School Students' Academic Motivation and Persistence in Mathematics. Journal of Educational and Developmental Psychology; Vol. 5, No. 1; 2015.

Suyanto, B. (2010). Masalah Sosial Anak. Jakarta: Kencana.

Suyanto, B. (2019). Sosiologi Anak. Jakarta: Kencanana

Zastrow, Charles (1996). Introduction to Social Work and Social Welfare. Pacific Grove: Brooks/Cole Publishing Company 